\title{
Spatial variability of physical, chemical, and biological properties of agricultural soils in Hidalgo State, Mexico
}

\author{
Prieto-Méndez, Judith ${ }^{1}$; Prieto-García, Francisco ${ }^{2 *}$; Acevedo-Sandoval, Otilio Arturo ${ }^{1}$; \\ Aquino-Torres, Eliazar ${ }^{2}$ \\ 1 Instituto de Ciencias Agropecuarias, Universidad Autónoma del Estado de Hidalgo. Carretera Pachuca- \\ Tulancingo, km 4.5. C. P. 42076. Pachuca, México. \\ 2 Instituto de Ciencias Básicas e Ingeniería. Universidad Autónoma del Estado de Hidalgo. Carretera Pachuca- \\ Tulancingo, km 4.5. C. P. 42076. Pachuca, México. \\ * Corresponding author: prietog@uaeh.edu.mx
}

Gitation: Prieto-Méndez, J., PrietoGarcía, F., Acevedo-Sandoval, O. A., \& Aquino-Torres, E., (2021). Spatial variability of physical, chemical, and biological properties of agricultural soils in Hidalgo State, Mexico. Agro Productividad. https://doi.org/10.32854/ agrop.v14i8.2040

Editor in Chief: Dr. Jorge Cadena Iñiguez

Received: February, 2021.

Accepted: July, 2021.

Estimated publication date: September, 2021

This work is licensed under a Creative Commons Attribution-NonCommercial 4.0 International license.

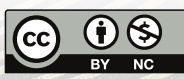

\section{ABSTRACT}

Objective: To establish the influence on soil fertility by spatial variations of physical, chemical, and biological properties of two agricultural soils in the state of Hidalgo (Mexico).

Methodology: Soils A, (clay-sandy, shallow horizon imperfect drainage), the municipality of Apan and soil B (with a light phase and thick, with stones), the municipality of Emiliano Zapata, were sampled in a network of $10 \times 10 \mathrm{~m}$ at 10,20 and $40 \mathrm{~cm}$ Deep. Four plots that have been under a malting barley monoculture system for more than 40 years were sampled. Physical, chemical and biological parameters were determined, following the official Mexican standard for soils.

Results: The $\mathrm{C} / \mathrm{N}$ ratio of both soils had a low spatial variation due to its relationship with stable fractions of soil organic matter (humus) and relatively low content. The spatial variability increased significantly with depth in both soils, while the apparent density showed little spatial variation. In addition, random behavior was observed at short distances (for available phosphorus, enzymatic activity and nitrates). The spatial variability of interaction between exchangeable bases, $\mathrm{K} /(\mathrm{Ca}+\mathrm{Mg})$ was greater than that of each element individually. The results showed that the concentrations of nutrients and the biological processes that affect their availability in the soil did not have a uniform spatial distribution, so that the applications in the fertilizer of the cultivated soil must adapt to these variations (site-specific fertilization).

Conclusions: There is a significant spatial of the soils dedicated for more than 40 years to the monoculture of malting barley. Nutrients and biological processes see their availability in soils affected. It is understood that applications of fertilizers to the soil are required to overcome and adapt to these variations (site-specific fertilization).

Keywords: soil fertility, spatial distribution, soil properties, geostatistics, spatial variability

\section{INTRODUGTION}

The increase in global food demand has considerably increased agricultural production in the last decades, requiring the use of crop varieties with high yields and the application of large amounts of fertilizer. Consequently, soil and water pollution 
has increased in proportion to the intensity of agriculture developed. Currently, global fertilizer use exceeds 195 million tons per year (FAO, 2008), which causes nitrate residue (>50 $\mathrm{mg} \mathrm{L}^{-1}$ ) and phosphate $\left(>0.1 \mathrm{mg} \mathrm{L}^{-1}\right)$ in aquifers above the permissible limits, and results in annual emissions to the atmosphere of $1400 \mathrm{kTon}$ carbon dioxide, methane 749 kTon and 81 kTon of nitrous oxide (Brethour et al., 2006). This has led to the development of agronomic practices that achieve high yields with less environmental impact, such as site-specific fertilization.

Site specific fertilization involves evaluating the spatial relationships of the properties of the soil and its effect on the crop yield. It has been observed that the spatial distribution of the physical, chemical, and biological soil, affecting the yield of a crop (Machado et al., 2002), however, the spatial dependence of the biological parameters of the soil has been underexplored. The purpose of this research was to study the nature of the spatial relationships of the physical, chemical, and biological properties of two agricultural soils used for growing malting barley (Hordeum distichum L.) for over 40 years as a monoculture and its influence on fertility thereof. These spatial relationships in these soils have not been reported in the literature.

\section{MATERIALS AND METHODS}

The study was conducted in two municipalities floors southern state of Hidalgo (Mexico). The average annual temperature, altitude and geolocation are indicated in Table 1. In these territories reaches an average rainfall of $1223 \mathrm{~mm}_{\text {year }}{ }^{-1}$.

Two soils were selected Cambisol, with contents of low activity clays, soil A (two plots of the municipality Apan) with clay loam and sandy shallow horizon $(26 \mathrm{~cm})$ with imperfect drainage, while the ground B (two plots of the municipality of Emiliano Zapata) with a light phase and thick, sandy-loam and stony (Prieto et al., 2011). Identified two plots of $3500 \mathrm{~m}^{2}$, with each soil type respectively.

The four plots have spent more than 40 years under a system of monoculture planted to malting barley. In early spring and in each experimental plot 40 soil samples taken in a network of $10 \times 10 \mathrm{~m}$, some samples were collected at $20 \mathrm{~cm}$ depth, and other samples every $10 \mathrm{~cm}$ to $40 \mathrm{~cm}$ deep. A portion of the samples were cooled to $4{ }^{\circ} \mathrm{C}$ until biological analyzes: mineralization potential nitrogen soil incubation in 14 days microbial respiration by $\mathrm{CO}_{2}$ evolution; urease activity by incubation of the soil with urea at $37^{\circ} \mathrm{C}$ and activity Acid and alkaline phosphatases soil by incubation at $37^{\circ} \mathrm{C}$ and colorimetry (Pinochet et al., 1997; Echevarria et al., 2000; Velascos et al., 2004).

The other part of the samples was air dried and sieved $(2 \mathrm{~mm})$ to determine the fractions of sand, silt and clay by hydrometer, Uhland cylinder bulk density, $\mathrm{pH} \mathrm{1:2}$ suspension, total Kjeldahl nitrogen, nitrate nitrogen and ammonia by acid digestion and alloy Devarda $\mathrm{MgO}$ and Kjeldahl distillation; Walkley organic carbon-Black, phosphorus,

Table 1. Location of sampling sites for municipalities.

\begin{tabular}{c|c|c|c|c}
\hline City & Latitude & Longitude & Altitude $(\mathbf{m})$ & Temperature $^{\circ} \mathbf{C}$ \\
\hline Apan & $19^{\circ} 41^{\prime} 16.6^{\prime \prime}$ & $98^{\circ} 23^{\prime} 33^{\prime}$ & 2547 & 14.1 \\
\hline E. Zapata & $19^{\circ} 54^{\prime} 16.0^{\prime}$ & $98^{\circ} 53^{\prime} 4^{\prime}$ & 2355 & 15.4 \\
\hline
\end{tabular}


potassium, calcium, and magnesium available Mehlich III (NOM-021-SEMARNAT, 2000). A soil samples taken every $10 \mathrm{~cm}$ depth was determined bulk density, organic carbon, and total nitrogen (NOM-021-SEMATNAT, 2000). The coefficient of variation and descriptive statistics were calculated using SAS statistical software (SAS Institute Inc., 1991). Geostatistical analyzes were performed using SPSS version 17.0 for Windows (Robertson, 2000; SPSS, 2007).

\section{RESULTS AND DISGUSIÓN}

In both soils, the plots of Apan and E. Zapata, the physical characteristics (bulk density and texture) showed coefficients of variation (CV) lower (between 2.91\% and $10.80 \%$ ) than those observed for chemical and biological parameters (see Table 2), which coincided with the observed by Melchiori and Echeverria (2000), Sun et al. (2003) and Gho (2004). Despite the differences in the grain size fractions showed textural variation

Table 2. Descriptive statistics of soil properties Apan series, phase-clay-sandy and Series E. Zapata, thick stage light, sandy loam at a depth of $20 \mathrm{~cm}$.

\begin{tabular}{|c|c|c|c|c|c|c|}
\hline \multirow{2}{*}{ Variable } & \multicolumn{3}{|c|}{ Ground Apan } & \multicolumn{3}{|c|}{ Ground Emiliano Zapata } \\
\hline & Mean & Std. Dev & $\mathbf{G V}^{1}(\%)$ & Mean & Std. Dev & $\mathbf{C V}^{1}(\%)$ \\
\hline Microbial respiration ( $\left.\mathrm{mg} \mathrm{CO}_{2} \mathrm{~g}^{-1} \mathrm{ss}\right)$ & 0.20 & 0.03 & 15.00 & 0.11 & 0.03 & 27.27 \\
\hline Urease activity $\left(\mu \mathrm{g} \mathrm{N}-\mathrm{NH}_{4} \mathrm{~g}^{-1} \mathrm{ss}\right)^{*}$ & 23.74 & 6.33 & 26.66 & 12.22 & 4.58 & 37.48 \\
\hline Activ. acid phosphatase $\left(\mu \mathrm{g} \text { PNP. } \mathrm{g}^{-1} \mathrm{ss}\right)^{* *}$ & 231.84 & 42.25 & 18.22 & 54.66 & 18.26 & 33.41 \\
\hline Activ. Alcal. phosphatase $\left(\mu \mathrm{g} \mathrm{PNP}^{-1} \mathrm{ss}\right)$ & 87.41 & 12.66 & 14.48 & 42.58 & 11.15 & 26.19 \\
\hline 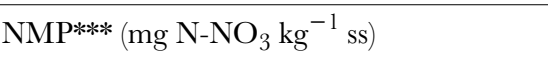 & 2.48 & 0.10 & 4.03 & 2.09 & 0.12 & 5.74 \\
\hline $\mathrm{OC}(\%)$ & 2.23 & 0.11 & 5.19 & 1.68 & 0.09 & 5.36 \\
\hline $\mathrm{N}$ total $(\%)$ & 0.13 & 0.01 & 10.44 & 0.11 & 0.01 & 10.79 \\
\hline $\mathrm{N}-\mathrm{NO}_{3}\left(\mathrm{mg} \mathrm{kg}^{-1} \mathrm{ss}\right)$ & 4.03 & 0.15 & 3.72 & 2.74 & 0.74 & 27.01 \\
\hline $\mathrm{N}^{-\mathrm{NH}_{4}}\left(\mathrm{mg} \mathrm{kg}^{-1} \mathrm{ss}\right)$ & 0.26 & 0.08 & 30.77 & 0.19 & 0.02 & 10.53 \\
\hline $\mathrm{C} / \mathrm{N}$ & 16.31 & 1.10 & 6.75 & 15.27 & 2.02 & 13.23 \\
\hline $\mathrm{P}$ disponible $\left(\mathrm{mg} \mathrm{kg}^{-1} \mathrm{ss}\right)$ & 0.17 & 0.01 & 6.75 & 0.11 & 0.02 & 18.18 \\
\hline $\mathrm{K}^{+}\left(\mathrm{mg} \mathrm{kg}^{-1} \mathrm{ss}\right)$ & 17.34 & 0.38 & 2.19 & 1.28 & 0.10 & 7.81 \\
\hline $\mathrm{Ca}\left(\mathrm{mg} \mathrm{kg}^{-1} \mathrm{ss}\right)$ & 34.55 & 0.91 & 2.63 & 69.27 & 1.88 & 2.71 \\
\hline $\mathrm{Mg}\left(\mathrm{mg} \mathrm{kg}^{-1} \mathrm{ss}\right)$ & 6.27 & 0.18 & 2.87 & 3.68 & 0.27 & 7.34 \\
\hline $\mathrm{K} /(\mathrm{Ca}+\mathrm{Mg})^{1 / 2}$ & 0.43 & 0.02 & 4.71 & 0.02 & 0.01 & 56.99 \\
\hline $\mathrm{Ca} / \mathrm{Mg}$ & 5.51 & 1.12 & 20.33 & 18.82 & 2.14 & 11.37 \\
\hline $\mathrm{Da}\left(\mathrm{g} . \mathrm{cm}^{-3}\right)$ & 1.16 & 0.08 & 6.90 & 1.03 & 0.03 & 2.91 \\
\hline Clay $(\%)$ & 55.86 & 2.54 & 4.55 & 12.50 & 1.35 & 10.80 \\
\hline Sand (\%) & 22.17 & 1.58 & 7.13 & 62.83 & 4.67 & 7.43 \\
\hline Moisture (\%) & 10.20 & 0.22 & 2.20 & 6.95 & 0.13 & 1.82 \\
\hline $\mathrm{pH}(1: 2)$ & 6.80 & 0.21 & 3.19 & 6.76 & 0.32 & 4.69 \\
\hline
\end{tabular}

${ }^{1}$ Coefficient of Variation

* Micrograms ammonia nitrogen produced in 1 hour incubation at $37^{\circ} \mathrm{C}$ Soil

** Micrograms p-nitrophenol phosphate produced in 1 hour incubation at $37^{\circ} \mathrm{C}$ Soil

*** Nitrogen mineralization potential $(\mathrm{t}=20$ days $)$

OC Organic carbon 
coefficients similar in both soils, although slightly higher for floors E. Zapata (Prieto $e t$ al., 2011).

The granulometric characteristics of each soil originated correlations with important variations in the moisture content thereof, and therefore affect its chemical and biological properties. In this way, variations in the average of both soil moisture in early spring and immobilization processes of nitrogen mineralization, were the causes of the high spatial variability shown by microbial activity, the nitrogen mineralization potential (NMP) and inorganic forms of nitrogen (Whitehead, 1995; Melchiori and Echeverria, 2000; Prasolova et al., 2000).

The coarse textured sandy soils and E. Zapata not favor microbial activity and their condition was less uniform (aerobic), so that the coefficient of variation of this soil microbial respiration was greater than Apan soils textured heavier and clay, although imperfect drainage. The lack of crop rotation and low microbial activity in the cold season, originated the high coefficients of variation of enzyme activity in both soils, much higher for the soils of E. Zapata as urease and phosphatases were not segregated in significant quantities by the roots of barley plants and soil microorganisms, respectively.

There is some relation between low variation nitrogen mineralization potential (PMN) and microbial activity with low variability exhibited by the types of organic materials which served as substrate in these biological processes as organic carbon and total nitrogen the $\mathrm{C} / \mathrm{N}$ showed coefficients of variation $<15 \%$ in both soils. Possibly, the total nitrogen (very low for both soils) as well as organic carbon (Boulding low by classification, 1995) were part of the stable fractions humus, whereas little variation shown by the relationship $\mathrm{C} / \mathrm{N}$, indicated that organic compounds of a similar nature were distributed throughout the soil (barley plant debris). Similar results were reported by Chevallier et al. (2000) and other authors in studies in different types of soils under agricultural production (Camacho et al., 2008; Outeiro et al., 2008).

Unlike Apan soils, phosphorus and potassium available soil E. Zapata showed high coefficient of variation (three times higher than Apan). Delcourt et al., (1996) and Sun et al. (2003) also found high coefficients of variation of phosphorus and potassium in soils with low organic carbon content and low nitrogen content. However, a high reactivity of the different fractions match with mineral soil caused high variability in space. Moreover, the thick texture and sandy soils E. Zapata, favored the movement of potassium with water flow in the profile, causing high variation of this element in the topsoil. Although $\mathrm{pH}$ is a factor that influences the availability of soil phosphorus, there was no relationship between the high variability shown by this element and the low coefficients of variation observed in the $\mathrm{pH}$ of both soils, no significant difference was observed in the values $\mathrm{pH}$ for both soils.

Magnesium saturates only $5-20 \%$ of the cation exchange capacity (CEC) in soils compared with saturating $\mathrm{Ca} 60-80 \%$ of CIC in neutral soils, as is the case study (Boulding, 1995). For good nutrition was said that needed a Ca/Mg 6:1 (corresponding to 65\%/10\% respectively CIC) (Brady and Weil, 2002). Relationships were found 5.51/1 to Apan soils, which is similar to that reported for proper nutrition to the cultivation of barley, but for floors E. Zapata was 18.8 /1, i.e. 3-4 times higher than the above. 
The overall predominant cation was $\mathrm{Ca}$, denoting the recent distribution of lime in the study area. Cations, as a whole, were those who showed greater variability, with $\mathrm{CV}$ values of $2-8 \%$. The spatial variability of the interaction $\mathrm{Ca} / \mathrm{Mg}$ showed independence of individual spatial variations of calcium and magnesium, in the two soils studied, whereas the coefficient of variation of potassium variability appears to influence the interaction shown by $\mathrm{K} /(\mathrm{Ca}+\mathrm{Mg})^{1 / 2}$, given the low content of $\mathrm{K}$ in all cases. It should be noted that the practice of liming soils usually performs in E. Zapata, which shows the great difference between the Ga content of soils.

This behavior is common for these elements in the soil, under agricultural production (Oliveira et al. 2009). On the other hand, it is stated that the contents of $\mathrm{K}$ in soil is one of the properties most affected by anthropic management, in terms of variability. Showed the lowest $\mathrm{pH}$ variability, which is commonly observed behavior for this property, in different types of soil at different depths (Camacho et al., 2008; Hurtado et al., 2009).

In both soils there was an increase in the spatial variability of organic carbon, total nitrogen and $\mathrm{C} / \mathrm{N}$ ratio with soil depth $0-20 \mathrm{~cm}$ is a slight increase then decreases significantly. The bulk density had a less fluctuating distribution in the soil profile (Table 3) tended to increase with depth, which corresponds to that reported by some authors (Alvarado and Forsythe, 2005). Variations observed variation coefficients from the $20 \mathrm{~cm}$ depth, which indicated the presence of organic compounds of different nature.

For this study, adjustments were made bounded models (spherical, exponential and gasussiano). Viera (2000) provides a discussion on the characteristics and the conditions they must meet. These models have three common parameters, which are the nugget effect (Co), Plateau $(\mathrm{Co}+\mathrm{C})$ and range or scope (Ao). Nugget effect indicates discontinuity

Table 3. Descriptive statistics of soil properties under study and its variations at depths of 0-40 $\mathrm{cm}$ in the A horizon.

\begin{tabular}{|c|c|c|c|c|c|c|c|}
\hline \multirow{2}{*}{ Variable } & \multirow{2}{*}{ Depth $(\mathbf{c m})$} & \multicolumn{3}{|c|}{ Ground Apan } & \multicolumn{3}{|c|}{ Ground Emiliano Zapata } \\
\hline & & Mean & Std. Dev & $\% \mathrm{CV}$ & Mean & Std. Dep & $\% \mathrm{CV}$ \\
\hline \multirow{4}{*}{$\mathrm{CO}(\%)$} & $0-10$ & 1.950 & 0.055 & 2.82 & 1.630 & 0.050 & 3.07 \\
\hline & $10-20$ & 2.260 & 0.072 & 3.19 & 1.702 & 0.083 & 4.88 \\
\hline & $20-30$ & 1.550 & 0.044 & 2.84 & 0.960 & 0.087 & 9.06 \\
\hline & $30-40$ & 0.860 & 0.048 & 5.58 & 0.760 & 0.075 & 9.87 \\
\hline \multirow{4}{*}{$\mathrm{N}_{\text {total }}(\%)$} & $0-10$ & 0.140 & 0.022 & 15.71 & 0.105 & 0.022 & 20.95 \\
\hline & $10-20$ & 0.126 & 0.021 & 16.67 & 0.120 & 0.033 & 27.50 \\
\hline & $20-30$ & 0.122 & 0.033 & 27.05 & 0.091 & 0.014 & 15.38 \\
\hline & $30-40$ & 0.081 & 0.011 & 13.58 & 0.064 & 0.011 & 17.19 \\
\hline \multirow{4}{*}{$\mathrm{C} / \mathrm{N}$} & $0-10$ & 13.929 & 2.500 & 17.95 & 15.524 & 2.273 & 14.64 \\
\hline & $10-20$ & 17.937 & 3.429 & 19.12 & 14.183 & 2.515 & 17.73 \\
\hline & $20-30$ & 12.705 & 1.333 & 10.49 & 10.549 & 6.214 & 58.91 \\
\hline & $30-40$ & 10.617 & 4.364 & 41.10 & 11.875 & 6.818 & 57.42 \\
\hline \multirow{4}{*}{$\mathrm{Da}\left(\mathrm{g} \mathrm{cm}^{3-1}\right)$} & $0-10$ & 1.160 & 0.080 & 6.90 & 1.030 & 0.030 & 2.91 \\
\hline & $10-20$ & 1.150 & 0.082 & 7.13 & 1.039 & 0.041 & 3.95 \\
\hline & $20-30$ & 1.291 & 0.076 & 5.89 & 1.184 & 0.047 & 3.97 \\
\hline & $30-40$ & 1.389 & 0.066 & 4.75 & 1.274 & 0.064 & 5.02 \\
\hline
\end{tabular}


between samples, i.e. spatial variability not detected during the sampling process, the mesa is semi-variance value, where the model is stabilized, exhibiting a constant and represents the distance range up where there is spatial correlation, indicating that correlation does not exist between samples.

The spherical model is defined by:

$$
\gamma_{(h)}=C_{o}+C *\left[1.5 *(h / a)-0.5 *(h / a)^{3}\right] \text { for } 0<\mathrm{h}<\mathrm{a} \text { and } \gamma_{(h)}=C_{o}+C \text { for } \mathrm{h}>\mathrm{a}
$$

The exponential model is defined by:

$\gamma_{(h)}=C_{o}+C *[1-e(-3 h / a)]$ for $0<\mathrm{h}<\mathrm{d}$,

where $d$ is the maximum distance at which the semi variogram is specified and the model Gaussian is defined by:

$\gamma_{(h)}=C_{o}+C *\left[1-e\left(-3 h^{2} / a^{2}\right)\right]$

Once the theoretical model of each property, verification of spatial dependence (DSM), by the ratio of the nugget effect and the plateau $\left(C / C_{0}+C\right)$. The GDE is classified as a sharp, if greater than 75\%, moderate between $25 \%$ and $75 \%$ and weak if less than $25 \%$ (Cambardella et al., 1994). It should be noted that it is desirable that the nugget effect does not exceed $50 \%$ of the plateau value for the model describes spatial correlation suitably reality (Cressie, 1993). When the DSM is near zero, the model fit the experimental variogram is called pure nugget effect (Goovaerts, 1998) and is defined by $\gamma_{(h)}=C_{o}$, for $\mathrm{h}>0$, denoting random spatial distribution of the property.

Both soils parameters showed a spatial structure anisotropic spherical set to an equation, and in some cases, an exponential model (Tables 4 and 5). In both soils, both available phosphorus and calcium showed the highest values of nugget effect, indicating a random behaviour at short distances. Jiang Jin (2002) explained that the random

Table 4. Anisotropic semi variogram parameters of physical, chemical, and biological soil Apan Township, a depth of $20 \mathrm{~cm}$.

\begin{tabular}{|c|c|c|c|c|c|c|}
\hline Property & Model & $\begin{array}{c}\text { Nugget Effect } \\
\left(\mathbf{C}_{\mathbf{o}}\right)\end{array}$ & $\begin{array}{c}\text { Plateau } \\
\left(C_{o}+C_{1}\right)\end{array}$ & $\begin{array}{c}\text { Range }^{2} \\
\left(\mathbf{A}_{\mathrm{o}}\right)\end{array}$ & $\begin{array}{c}\text { Proportion }^{3} \\
C_{1} /\left(C_{o}+C_{)}\right)\end{array}$ & $\mathbf{R}^{2}$ \\
\hline Magnesium ( $\left.\mathrm{mg} \mathrm{kg}^{-1} \mathrm{ss}\right)$ & Exponential & 8.45 & 27.13 & 7.21 & 0.748 & 0.853 \\
\hline Calcium $\left(\mathrm{mg} \mathrm{kg}^{-1} \mathrm{ss}\right)$ & Spherical & 12031.36 & 4516.32 & 22.58 & 0.816 & 0.945 \\
\hline $\mathrm{Ca} / \mathrm{Mg}$ & Spherical & 0.15 & 12.15 & 18.74 & 0.929 & 0.859 \\
\hline Phosphorus (mg kg $\left.{ }^{-1} \mathrm{ss}\right)$ & Spherical & 12.58 & 48.66 & 128.76 & 0.724 & 0.933 \\
\hline $\mathrm{pH}$ & Spherical & 0.031 & 0.132 & 23.08 & 0.753 & 0.942 \\
\hline clay $(\%)$ & Spherical & 0.011 & 3.658 & 26.37 & 1.002 & 0.911 \\
\hline $\mathrm{Da}\left(\mathrm{g} \mathrm{cm}^{-3}\right)$ & Spherical & 0.002 & 0.003 & 148.74 & 0.871 & 0.823 \\
\hline
\end{tabular}

\footnotetext{
${ }^{1}$ Umbral of semi variance where there is spatial dependence $(\mathrm{C})$ and random behavior of the variable $(\mathrm{Co})$.

${ }^{2} \mathrm{Sw}$ Distance spatial dependence in meters $(\mathrm{m})$.

${ }^{3}$ Proporción spatial dependence $(\mathrm{C})$ of the total random structure $(\mathrm{Co})$ more regionalized $(\mathrm{C})$ of the variable.
} 
Table 5. Anisotropic semivariogram parameters of physical, chemical and biological soil Township E. Zapata, a depth of $20 \mathrm{~cm}$.

\begin{tabular}{|c|c|c|c|c|c|c|}
\hline Property & Model & $\begin{array}{c}\text { Nugget } \\
\text { Effect }\left(\mathbf{C}_{\mathbf{o}}\right)\end{array}$ & $\begin{array}{c}\text { Plateau } \\
\left(\mathbf{C}_{\mathbf{o}}+\mathrm{C}\right)\end{array}$ & $\begin{array}{c}\text { Range }^{2} \\
\left(\mathbf{A}_{\mathrm{o}}\right)\end{array}$ & $\begin{array}{c}\text { Proportion }^{3} \\
C_{1} /\left(C_{o}+C_{)}\right)\end{array}$ & $\mathbf{R}^{2}$ \\
\hline Microbial respiration $\left(\mathrm{mg} \mathrm{CO}_{2} \mathrm{~g}^{-1} \mathrm{ss}\right)$ & Exponential & 0.001 & 0.010 & 141.25 & 0.789 & 0.895 \\
\hline Urease activity $\left(\mu \mathrm{g} \mathrm{N}-\mathrm{NH}_{4} \mathrm{~g}^{-1} \mathrm{ss}\right)^{*}$ & Spherical & 28.55 & 168.42 & 136.48 & 0.857 & 0.977 \\
\hline Activ. acid phosphatase $\left(\mu \mathrm{g} \mathrm{PNP} \mathrm{g}^{-1} \mathrm{ss}\right)^{* *}$ & Spherical & 1383.24 & 4369.5 & 38.24 & 0.688 & 0.975 \\
\hline Activ. Alcal. phosphatase $\left(\mu \mathrm{g} \mathrm{PNP} \mathrm{g}^{-1} \mathrm{ss}\right)$ & Spherical & 0.85 & 421.56 & 41.22 & 0.987 & 0.842 \\
\hline $\mathrm{NMP}^{4}\left(\mathrm{mg} \mathrm{N}-\mathrm{NO}_{3} \mathrm{~kg}^{-1} \mathrm{ss}\right)$ & Spherical & 0.74 & 6.87 & 57.49 & 0.896 & 0.947 \\
\hline $\mathrm{OC}(\%)$ & Spherical & 0.02 & 0.115 & 47.58 & 0.989 & 0.972 \\
\hline $\mathrm{N}$ total $(\%)$ & Spherical & 0.003 & 0.004 & 35.56 & 0.966 & 0.946 \\
\hline $\mathrm{N}-\mathrm{NO}_{3}\left(\mathrm{mg} \mathrm{kg}^{-1} \mathrm{ss}\right)$ & Exponential & 2.66 & 8.77 & 129.38 & 0.623 & 0.885 \\
\hline $\mathrm{C} / \mathrm{N}$ & Spherical & 0.217 & 1.012 & 65.87 & 0.745 & 0.968 \\
\hline $\mathrm{P}$ available $\left(\mathrm{mg} \mathrm{kg}^{-1} \mathrm{ss}\right)$ & Spherical & 9.32 & 79.89 & 30.15 & 0.874 & 0.959 \\
\hline $\mathrm{K}^{+}\left(\mathrm{mg} \mathrm{kg}^{-1} \mathrm{ss}\right)$ & Spherical & 275.34 & 1045.32 & 137.26 & 0.658 & 0.974 \\
\hline $\mathrm{Ca}\left(\mathrm{mg} \mathrm{kg}^{-1} \mathrm{ss}\right)$ & Spherical & 14607.6 & 34256.52 & 140.26 & 0.487 & 0.845 \\
\hline $\mathrm{K} /(\mathrm{Ca}+\mathrm{Mg})^{1 / 2}$ & Spherical & 0.000 & 0.001 & 184.32 & 0.768 & 0.796 \\
\hline $\mathrm{Da}\left(\mathrm{g} \mathrm{cm}^{-3}\right)$ & Spherical & 0.001 & 0.006 & 49.74 & 0.823 & 0.963 \\
\hline Clay (\%) & Spherical & 0.074 & 8.89 & 25.69 & 0.912 & 0.921 \\
\hline $\mathrm{pH}(1: 2)$ & Spherical & 0.045 & 0.174 & 128.72 & 0.687 & 0.869 \\
\hline
\end{tabular}

${ }^{1}$ Umbral of semi variance where there is spatial dependence $(\mathrm{C})$ and random behavior of the variable $\left(\mathrm{C}_{\mathrm{o}}\right)$.

${ }^{2} \mathrm{Sw}$ Distance spatial dependence in meters $(\mathrm{m})$.

${ }^{3}$ Proporción spatial dependence $(\mathrm{G})$ of the total random structure $\left(\mathrm{G}_{\mathrm{o}}\right)$ more regionalized $(\mathrm{C})$ of the variable.

${ }^{4}$ Potential for nitrogen mineralization ( $\mathrm{t}=20$ days).

$\mathrm{OC}=$ Organic carbon.

structure of phosphorus short distances was caused by its high interaction with the solid phase of the soil.

In soils E. Zapata, available phosphorus showed higher spatial dependence (86) and a nugget effect (9.32) lower than in soils of Apan (12.38). In parallel, the pH, bulk density and clay fraction showed nugget effect with values close to zero and a strong spatial dependence (>75\%) in both soils (Figures 1 and 2).

The $\mathrm{pH}$ of both soils showed a moderate spatial structure and very low nugget effect (0.031-0.045). Delcourt work et al. (2000) reported a strong spatial dependence of pH on mineral soils, indicating that these soils are only moderately mineralized. In both soils, the ranges (Ao) of spatial dependence were very wide and many soil variables showed a spatial structure dependent on the direction of the observations (anisotropy).

In soils of Apan, total nitrogen and $\mathrm{C} / \mathrm{N}$ ratio remained random behavior with soil depth (Table 3), while for the organic carbon found spatial structure described by an exponential equation from the $20 \mathrm{~cm}$ deep. The bulk density had a spatial continuity with spherical structure to $20 \mathrm{~cm}$ deep from this depth had a random behaviour. In soils E. Zapata, the spatial dependence of the total nitrogen, organic carbon, the $\mathrm{C} / \mathrm{N}$ and the bulk density at different depths were described by spherical models. In these soils, 20-30 cm depth, there was no spatial dependence of these variables, which coincided with a significant increase in coefficient of variation. 

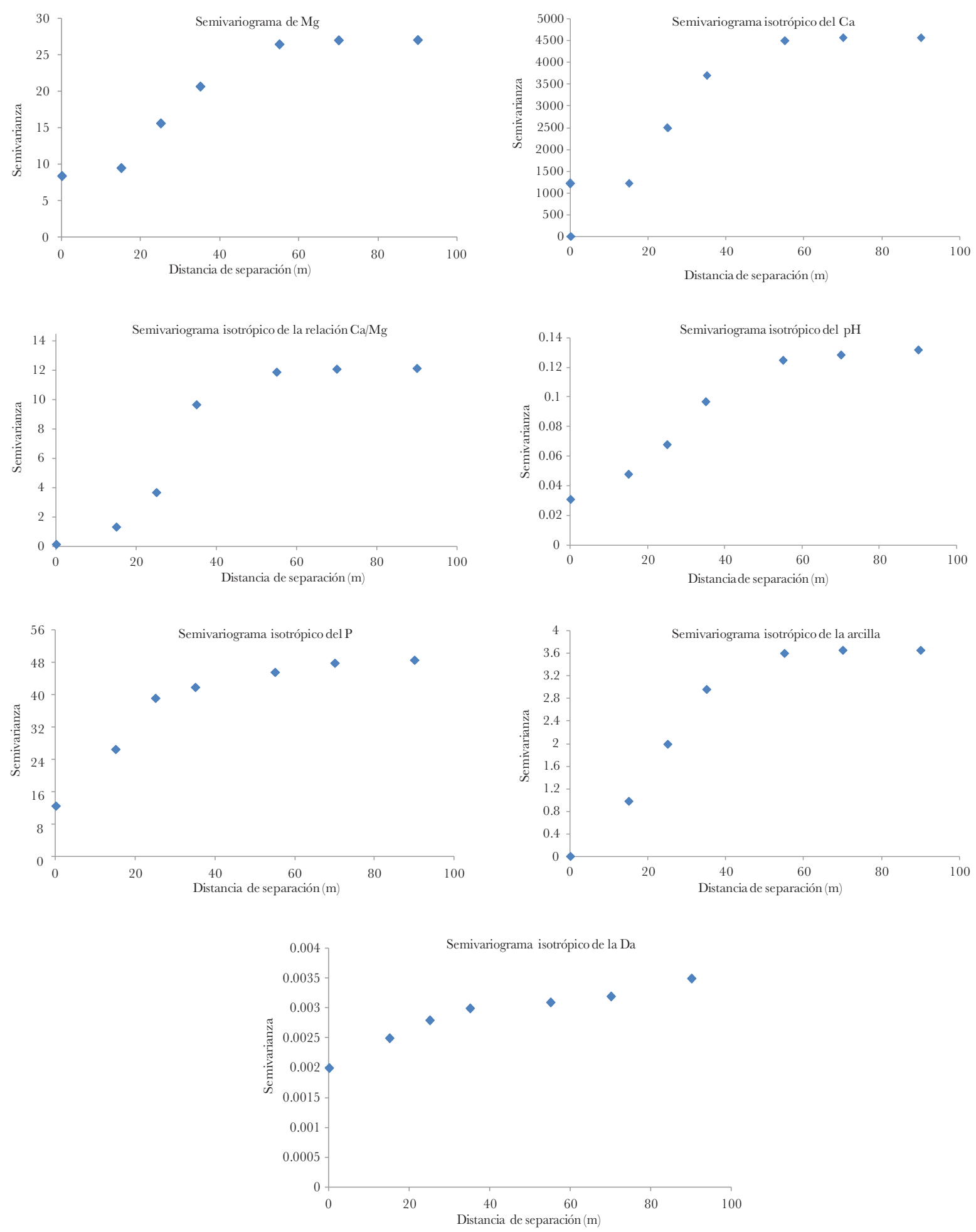

Figure 1. Omnidirectional semivariograms of physical, chemical, and biological Apan soils to a depth of $20 \mathrm{~cm}$. 

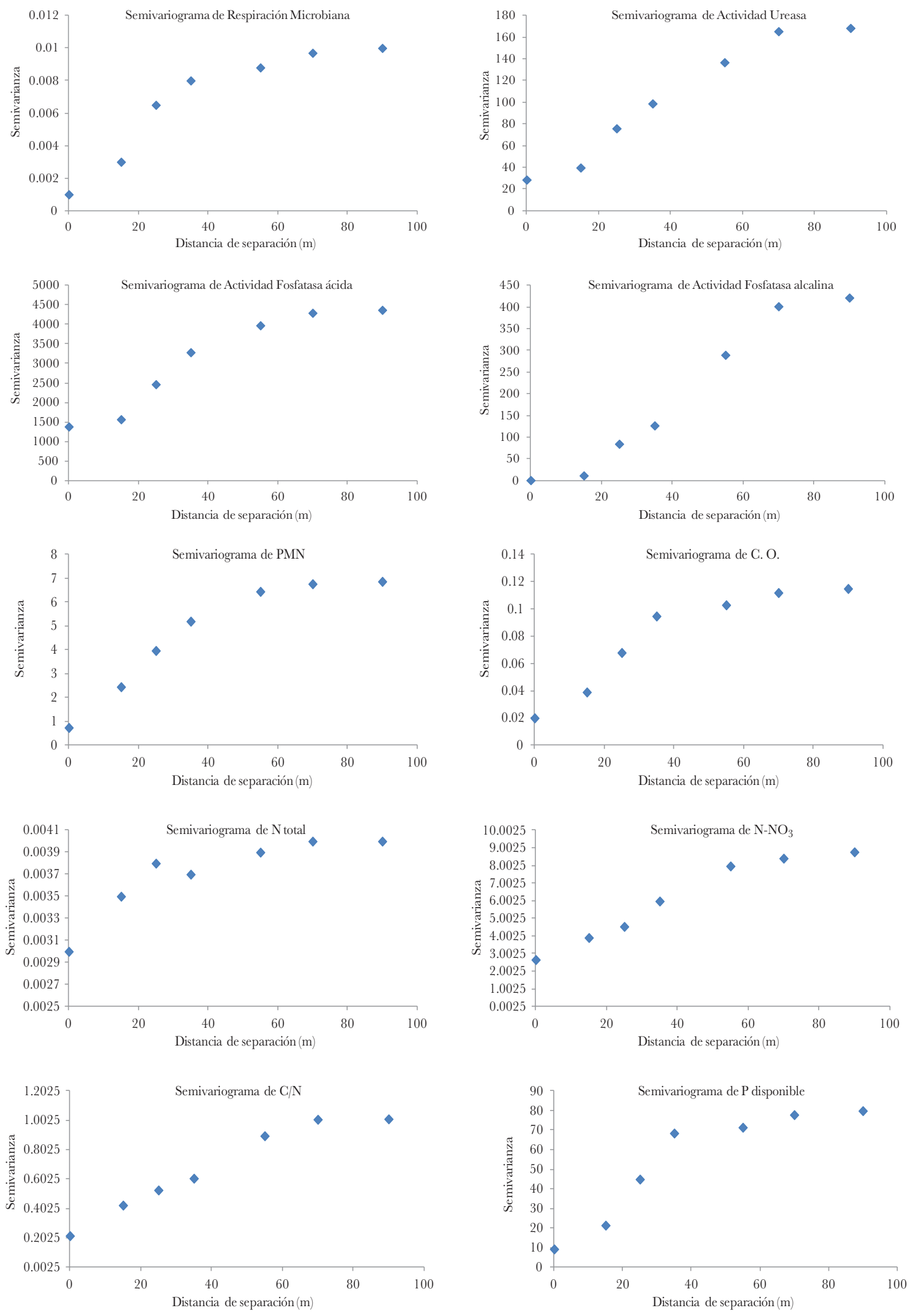

Figure 2. Omnidirectional semivariograms physical and chemical properties of soils of Emiliano Zapata, at a depth of $20 \mathrm{~cm}$ 


\section{CONGLUSIONS}

The fineness of the soil, moisture content-mineralization processes immobilization and changes in the nature of the organic compounds affect the spatial distribution of the physical, chemical, and biological properties of the soils studied. The physical properties exhibited coefficients of variation lower than the chemical and biological properties for both types of soil, indicating that the biochemical parameters showed a very complex dynamic, while the physical characteristics of the soil generally exhibited a more uniform distribution. Organic carbon, total nitrogen and $\mathrm{C} / \mathrm{N}$ ratio of both soils had low spatial variation due to his relationship with stable fractions of soil organic matter (humus) and relatively low content. Variability in the space of organic carbon, total nitrogen and $\mathrm{C} / \mathrm{N}$ ratio increased significantly with depth in the two soils studied, whereas the apparent density showed little spatial variation. Random behavior at short distances (nugget effect) observed for phosphorus available, enzyme activity and nitrates in the two floors, it may be caused by moisture variations thereof mineralization processes, nitrogen immobilization, the little reactivity with the phosphorus content of the soil solid phase, among other causes. The spatial variability of the interaction between exchangeable bases, $\mathrm{K} /(\mathrm{Ca}+\mathrm{Mg})$ was higher than that of each element individually; showing independence in the spatial behavior associated perhaps low potassium. The results showed that concentrations of nutrients and biological processes affecting their availability in soil did not have a uniform spatial distribution, whereby applications in the cultivated soil fertilizer must accommodate these variations (site specific fertilization).

\section{REFERENCES}

Alvarado, A., Forsythe, W. (2005). Variation of bulk density in soil orders of Costa Rica. Costa Rican Agriculture, 29 (1): 85-94.

Boulding, JR. (1995). Description and sampling of contaminated soils. A field guide, 2nd ed. Boca Raton, FL7 Lewis Publishers.

Brady, N., Weil, R. (2002). Soil acidity: Calcium and Magnesium as plant nutrients. 404-410.

Brethour, C., T. Moore and D. Bucknell. (2006). Évaluation des incidences environnementales et Economiques des Règlements environnementaux pour le secteur agricole. Une étude de cas sur l'Elevage de porcins. Agriculture et Agroalimentaire Canada. George Morris Centre. 179 p. Disponible en: http://www4. agr.gc.ca/resources/prod/doc/pol/pub/hog-porc/pdf/hog-porc_f.pdf

Camacho-Tamayo, J. H., Luengas, C. A., Leiva. F. R. (2008). Effect of agricultural intervention on the spatial variability of some chemical properties of soils in the Eastern Planes of Colombia. Chilean J. Agr. Res, 68 (1) :42-55. Doi: 10.4067/S07 18-58392008000100005

Cambardella, C. A., Moorman, T. B.; Novak, J. M., Parkin, T. B.; Karlen, D. L., Turco, R. F.; Konopka, A. E. (1994). Field-scale variability of soil properties in Central Iowa Soils. Soil Sci. Soc. Am. J., 58 (5) :15011511. Doi: 10.2136/sssaj1994.03615995005800050033x

Chevallier, T., M. Voltz, E. Blanchart, J.L. Chotte, V. Eschenbrenner, M. Mahieu., A. Albrecht. (2000). Spatial and temporal changes of soil $\mathrm{C}$ after establishment of a pasture on a long term cultivation Martinique. Geoderma vertisol 94 (1). 43-58. Doi: 10.1016/S0016-7061(99)00064-6

Cressie, N. (1993). Statistics for spatial data, John Wiley \& Sons, New York. 928p.

Delcourt, H., P. L. Darius., J. F. Baerdemaeker. (1996). The spatial variability of some aspects of topsoil fertility in two Belgian fields. Computers and Electronics in Agriculturle. 14:179-196. Doi: 10.1016/01681699(95)00047-X

Echeverría, H. E., St. Martin, N. F., Bergonzi, R. (2000). Rapid methods of estimating potentially mineralizable nitrogen in soils. Soil Science, 18 (1) p. 9-16.

FAO, (2008). Current world fertilizer trends and outlook to 2011/12. Food and Agriculture Organization of United Nations, Rome. 57 p. Disponible en: ftp://ftp.fao.org/agl/agll/docs/cwftol 1.pdf 
Gho B., C. (2004). Spatial variability of soil chemical properties and their relationship to yields of maize (Zea mays L.). Monograph. Pontifical Catholic University of Chile, Faculty of Agriculture and Forestry, Department of Plant Sciences. Disponible en: http://www.uc.cl/agronomia/e_publicaciones/Articulos/ articulos.htm

Goovaerts, P. (1998). Geostatistical tools for characterizing the spatial variability of microbiological and physico-chemical soil properties. Biol Fert. Soils. 27 (4) :315-334.

Hurtado, S. M. C., Silva, C. A., Resende, A. V. De; Von Pinho, R. G.; Inacio, E. S. B., Higas-hikawa, F. S. (2009). Spatial variability of soil acidity attributes and the spatialization of liming requirement for corn. Ciência e Agrotecn. 33 (5) :1351-1359. Doi: 10.1590/S1413-70542009000500022

Jin J., Jiang, C. (2002). Spatial variability of soil nutrients and site-specific nutrient management in the PR China. Computers and Electronics in Agriculture 36 (2):165 -172. Doi: 10.1016/S0168-1699(02)00099-6

Machado, S., E. D. Bynum Jr., T. Archer, R. Lascano, J. Bordovsky, K. Bronson, D. Nesmith, E. Segarra, D. Rosenow, G. Peterson, W. Xu., Wilson, L. (2002). Spatial and temporal variability of sorghum and corn yield: interactions of biotic and abiotic factors. Proceedings of the 5th International Conference on Precision Agriculture, Bloomington, Minnesota, USA, 16-19 July. American Society of Agronomy, Madison, USA.

Melchiori, R. J., Echeverria, H. (2000). Spatial variability in soil properties: I. Association with variations in the yield of wheat. Disponible en: http://www.agriculturadeprecision.org/articulos/mansit.htm

Moulin, A., D. Derksen, D. McLaren., Grant, C. (2002). Spatial variability of soil fertility and identification of management zones on hummocky terrain. Brandon Research Centre, Agriculture and Agri-Food Canada, Brandon. 3rd. Annual Manitoba Agronomists Conference, 2002. December 10-11.

Official Mexican Standard (2000). NOM-021-SEMARNAT-2000. Establishing the specifications of fertility, salinity and soil classification. Studies, sampling and analysis. Mexico.

Oliveira, P. C. G., Farias, P. R. S., Lima, H. V.; Fernande, A. R.; Oliveira, F. A., Pita, J. D. (2009). Spatial Variabilidade chemical properties do alone and gives Productivity of Amazonian nania citros East. Rev. Bras. Engenharia Agr. Amb. 13 (6) :708-715.

Outeiro, L.; Asperó, F., Ubeda, X. (2008). Geostatistical methods to study spatial variability of soil cations after a prescribed fire and rainfall. Catena. 74 (3):310-320. Doi: 10.1016/j.catena.2008.03.019

Paz-Gonzalez, A., S. R. Vieira., Taboada, M.T C. (2000). The effect of cultivation on the spatial variability of selected properties of an umbric horizon. Geoderma 97:273-292. Doi: 10.1016/S0016-7061(00)00066-5

Pinochet, D., Mendoza, J., Galvis, J. (1997). Nitrogen mineralization potential of a Hapludand with different agricultural managements. Hundred. Investig. Agr. 27 (2) :97-106.

Prasolova, N. V., Z.H. XUB, P. G. Safagnaa and M.J. Dieters. (2000). Spatial-temporal variability of soil moisture, nitrogen availability indices and other chemical properties in hoop pine (Araucaria cunninghamii) plantations of subtropical Australia. Forest Ecology and Management.136:1-10. Doi: 10.1016/S0378-1127(99)00254-6

Prieto-Mendez, J., Rubio-Arias, H., Prieto-Garcia, F., Roman-Gutierrez, A. D., Mendez-March, M. A., Acevedo-Sandoval, O. A. (2011). Soil Quality in Terms of Physical-Chemical-Metal Properties for Barley (Hordeum vulgare) Production in the State of Hidalgo, Mexico. American-Eurasian J. Agric. \& Environ. Sci, 10 (2): 230-237.

Robertson, G. (2000). Geostatistics for the environmental science. GS + for Windows v. 5.1 Gamma Design Software.

SAS Institute Inc. (1991). SAS / STAT. User's guide. Version 6.03. Fourth edition, vol. 1. Cary, NC, SAS Institute Inc.

SPSS 17.0. (2007). User Manual SPSS Statistics Base 17.0. SPSS Inc. 233 South Wacker Drive, 11 th Floor, Chicago, IL 60606-6412, USA

Sun, B., S. Zhou., Zhao, Q. (2003). Evaluation of spatial and temporal changes of soil quality based on geostatistical analysis in the hill region of subtropical China. Geoderma 115:85-99. Doi: 10.1016/S00167061(03)00078-8

Velasco-Velasco, J., Figueroa-Sandoval, B., Ferrera-Cerrato, R. 2004. Trinidad-Santos, A., Gallegos-Sanchez, J. CO2 and microbial population dynamics of manure and straw compost aerated. TERRA,22, (3).307316.

Whitehead, D.C. (1995). Grassland nitrogen. CAB International, Wallingford, UK. 397 p. 